\title{
The Effect of a Gender-Residential Location and Education Level in Response to Regulation of Corona Virus Disease-19 Distribution and Prevention in Social Studies Student
}

\author{
Ketut Prasetyo ${ }^{1, *}$ Nasution ${ }^{1}$ Sukma Perdana Prasetya ${ }^{1}$ Dian Ayu Larasati ${ }^{1}$ \\ ${ }^{1}$ Social Studies Program, Universitas Negeri Surabaya, Surabaya, Indonesia \\ "Corresponding author. Email: ketutprasetyo@unesa.ac.id
}

\begin{abstract}
Efforts to reduce the spread of Corona Virus Disease-19 have been heavily regulated by the government. Likewise, the campus has also made various regulations to prevent the transmission of Corona Virus Disease-19. In connection with the Corona Virus Disease-19 pandemic which has lasted for approximately 1 year, the campus regulations that have been implemented need to be known about student responses. Because with various backgrounds from students, gender and educational strata are possible to have different responses in facing the regulations that have been implemented in the campus environment. By survey method for students of Social Sciences, State University of Surabaya to find out their responses to regulations. Meanwhile, the sampling method was chosen proportionally randomly, and the data collection method was done online. Then to find out the differences in student responses, the data that has been collected is processed by logistic regression. Finally, it is known that social science students in responding to regulations to prevent the spread of Corona Virus Disease-19 are in the poor category. Then, it is known that in detail students who live in the city of Surabaya respond to regulations to prevent the spread of Corona Virus Disease- 19 higher when compared to students living outside the city of Surabaya. Then students at the undergraduate education level have a lower response when compared to the response of Masters students, and the response of male students is lower in response to regulations on the prevention and spread of Corona Virus Disease-19 when compared to the response of the female student group.
\end{abstract}

Keywords: Residential, Gender, Education, Response, Regulation, Covid-19

\section{INTRODUCTION}

Indonesia has confirmed the first Corona Virus Disease19 case on March 6, 2020, with 2 sufferers [1]. Then until January 27, 2020, the confirmed number was 1,012,350, the number of new cases was 13,094, and the number of sufferers who died was 28,468 . Thus it is a warning for the Indonesian government to be more serious in preventing the transmission of Covid19. One of the Indonesian Government strategies in suppressing the spread of Corona Virus Disease-19 is to issue
Government Regulations.Number 21 of 2020 concerning Large-Scale Social Restrictions. Meanwhile, the technical details of the implementation are regulated through the Regulation of the Minister of Health of the Republic of Indonesia number 9 of 2020 concerning Guidelines for Large-Scale Social Restrictions in the context of the Acceleration of Handling Corona Virus Disease 2019. Now, Corona Virus Disease-19 for urban and rural 
Table 1. Global and Indonesia Corona Virus Disease-19 [1 ]

\begin{tabular}{|c|c|c|c|c|}
\hline Nam & $\begin{array}{r}\text { Cases } \\
\text { Cumulative } \\
\text { Total }\end{array}$ & \begin{tabular}{l}
\multicolumn{1}{c}{ Cases New } \\
lay Reported In \\
Last 24 Hour
\end{tabular} & $\begin{array}{l}\text { Deaths - cumulativ } \\
\text { e total }\end{array}$ & $\begin{array}{l}\text { Deaths - newly } \\
\text { reported in last } \\
24 \text { hours }\end{array}$ \\
\hline Glob & $99,864,391$ & 468,808 & $2,149,700$ & 12,856 \\
\hline nesia $^{\text {Indo }}$ & $1,012,350$ & 13,094 & 28,468 & 336 \\
\hline
\end{tabular}

communities in Indonesia have known its existence such as in Simerta Village, Bali. Almost all the Simerta villagers have known the Corona Virus Disease-19 pandemic awareness and practiced all of the behavior about it [2] but they seldom still indiscipline about it [3]. The situation of low compliance with the implementation of the Corona Virus Disease-19 protocol also seems to exist in Corona Virus Disease-19 volunteers [4][5]

Regulations on the prevention and spread of the disease19 coronavirus were enforced on the State University of Surabaya campus since students were affected by Corona Virus Disease-19 in Wuhan-China. At the beginning of Corona Virus Disease-19, 11 students of the State University of Surabaya were exposed to Corona Virus Disease-19 in Wuhan. The form of initial regulations imposed by the State University of Surabaya campus was to isolate these ex-Wuhan students. Then, based on the continued number of exposed academicians, the State University of Surabaya campus imposed lockdowns on several occasions. Regulations aimed at preventing and spreading Corona Virus Disease-19 require the adaptability of all individual components of the campus community. Adaptation is a change in behavioral responses to suit environmental conditions. Referring to Bell's environmental adaptation theory [6] individuals to adapt to the environment require the ability to carry out copying (action) to adapt themselves or adapt to the environment to their condition. As a result of copying behavior, there are two possibilities. First, this copying behavior did not bring the expected results. This failure of copying causes stresses to continue. Second, successful coping behavior.

According to Bell's theory, student responses in adapting/copying with regulations to prevent the spread of Corona Virus Disease-19 in a pandemic environment can be successful or likely to fail. High exposure to regulation means that individuals are assumed to be able to adapt to the regulations that are enforced, but a low response is assumed that individuals fail to adapt to regulations to prevent the spread of Corona Virus
Disease-19 on campus. As the research target chosen was a group of Social Science students. Thus, the assumptions in this study, by selecting social studies students is built that the results of social studies student responses to prevention and dissemination regulations Coronavirus disease-19 is higher or the response can adjust or agree more in implementing regulations

\section{METHOD}

Through a survey method on the object of social science students and data processing using logistic regression, then the research objective to be achieved is to analyze the effect of differences in student responses. The differences analyzed were based on origin/location of residence, gender, and level of education in responding to regulations on preventing the spread of Coronavirus Disease-19. Based on the findings of the research on student response regulations on preventing the spread of Coronavirus Disease- 19, it is expected that it can become an evaluation material as well as for improving the regulations that have been set.

\section{RESULTS AND DISCUSSIONS}

Response in general understanding is defined as when someone reacts through thoughts, attitudes, and behavior [7]. The students in response to the regulation of preventing the spread of Corona Virus Disease- 19 on the campus of the State University of Surabaya with an average score of 46.80 are in a low category. Overall, to find out the student response score in adapting to the regulations for preventing the spread of Corona Virus Disease-19 is presented as in Table 2

The order of student response scores to regulations from the highest to the lowest, namely online guidance, work from home, the use of journals as a substitute for a thesis or thesis, online administration services, online lectures, and the lowest in the online graduation plan. The response of female students with a score of 46.6 is higher when compared to the response of male students with 
Table 2. Scores of Student Responses Regulations to Prevent the Spread of Corona Virus Disease-19

\begin{tabular}{|c|c|c|c|c|c|c|c|c|}
\hline \multirow[b]{2}{*}{ No. } & \multirow[b]{2}{*}{ Regulation } & \multirow[b]{2}{*}{$\begin{array}{l}\text { Averag } \\
e \\
\text { Scores }\end{array}$} & \multicolumn{2}{|c|}{ Gender } & \multicolumn{2}{|c|}{ Education } & \\
\hline & & & Male & $\begin{array}{l}\text { Fema } \\
\text { le }\end{array}$ & $\begin{array}{l}\text { Magist } \\
\text { er }\end{array}$ & $\begin{array}{l}\text { Bachel } \\
\text { or }\end{array}$ & $\begin{array}{l}\text { location } \\
\text { Inside } \\
\text { City }\end{array}$ & $\begin{array}{l}\text { Outsi } \\
\text { de } \\
\text { City }\end{array}$ \\
\hline 1. & Work From Home & 52.40 & 60.0 & 50.8 & 57.22 & 51.26 & 58.64 & 58.11 \\
\hline 2. & On-line lectures & 45.10 & 42.0 & 43.4 & 60.77 & 39.46 & 63.78 & 35.33 \\
\hline 3. & $\begin{array}{l}\text { Onl-ine academic } \\
\text { consultation }\end{array}$ & 58.54 & 64.0 & 46.9 & 71.22 & 43.68 & 67.57 & 41.27 \\
\hline 4. & On-line Services & 45.70 & 36.0 & 51.4 & 37.88 & 52.56 & 45.44 & 51.66 \\
\hline 5. & $\begin{array}{l}\text { Jurnal as substitution a } \\
\text { essay }\end{array}$ & 49.92 & 40.0 & 46.6 & 48.68 & 45.00 & 35.00 & 49.86 \\
\hline 6. & $\begin{array}{l}\text { On-line graduation } \\
\text { Average scores }\end{array}$ & $\begin{array}{l}39.12 \\
46.80\end{array}$ & $\begin{array}{l}56.0 \\
40.3\end{array}$ & $\begin{array}{l}37.0 \\
46.6\end{array}$ & $\begin{array}{l}56.66 \\
45.96\end{array}$ & $\begin{array}{l}52.56 \\
39.73\end{array}$ & $\begin{array}{l}50.21 \\
45.07\end{array}$ & $\begin{array}{l}32.94 \\
44.87\end{array}$ \\
\hline
\end{tabular}

40.3. Then based on logistic regression analysis it is known that $\mathrm{r}=0.059134907$, meaning that the response of female students is $5.9 \%$ greater than the response of male students.

The average response of Masters students is 45.96, so this fact is higher when compared to the response of undergraduate students which is only 39.73 . Then based on logistic regression analysis, the correlation value is 0.21242455 . Thus it can be interpreted that a higher level of education has a higher response to the regulation of preventing the spread of Corona Virus Disease-19 when compared to lower education levels. That the response of students living in Surabaya has a $27.05 \%$ greater response when compared to the response of students living outside the city of Surabaya, especially in responding to the regulation of prevention of transmission of Corona Virus Disease-19 which is implemented on campus.

Based on the results of the study, the respondent's response classification was categorized into 4, namely: very good response (score> 75-100); good response (score> 50-75); poor response (score 25-50); and the response is very poor $(<25)$, so the overall student response score of 46.80 is said to be less. This means that in responding or responding to campus regulations regarding efforts to prevent the spread of Corona Virus Disease-19 to students of the State University of Surabaya, the response is lacking or low. Less or low response to a phenomenon if allowed to accumulate, will cause stress. Then if the amount of stress is experienced by a person so much, the impact is dangerous to his physical and mental condition [8]. In discussing stress when referring to Bell's environmental adaptation theory [6] Surabaya State University students in facing stressors in the form of regulations to prevent the spread of Corona Virus Disease-19, then theoretically they can either copy or fail in adapting. If it is assumed that a low response can be identified as a source of stress, then the lowest student response to online lectures can be assumed to be a source of stress. The use of an online system in the Corona Virus Disease-19 pandemic seems to force all humans to be prepared for current technological developments [9][10] [11]. Thus, the results of this study confirm that the online lecture process during the pandemic is a source of problems that need attention.

The Effect of Gender on Regulation to Prevent the Spread of Corona Virus Disease-19 is response score of 46.6 for the female student group is still classified as less, but in relation to the characteristics of women who are more diligent and obedient to the rules than men, the characteristics of female students have the potential to be improved, especially in participating in the prevention of transmission of Corona Virus Disease-19. Referring the statement of the Chair of the Task Force for the Acceleration of Handling Corona Virus Disease-19 [12]. This clearly shows the real contribution of women in handling the Corona Virus Disease-19 pandemic in Indonesia. The Effect of Education Strata on Regulation to Prevent the Spread of Corona Virus Disease-19, it is known that the response of master students has a higher response when compared to undergraduate students regulations for preventing the spread of Corona Virus Disease-19 [13] The Effect of Residential Location on Regulation to Prevent the Spread of Corona Virus Disease-19, that the condition of the location distance affects the quality of communication using the internet network [14] [15] [16]. Based on the theory that the location of residence affects the quality of internet connection, $80 \%$ of students who live outside the city of Surabaya have the potential not to receive a good network. Thus, they will experience interference or stress 
during the implementation of internet networks usage activities such as lectures, tutoring, or online graduation.

\section{CONCLUSION}

The response of social science students to regulations in adapting to the new Covid-19 environment has caused saturation, stress, especially in internet users in the field of academic services. A relatively strong response in adapting to Covid-19 regulations was found in student groups: male gender, location of residence in the city, and postgraduate education level

\section{ACKNOWLEDGMENTS}

This paper is produced from research funded by PNBP of the Faculty of Social Sciences and Law, State University of Surabaya for Fiscal Year 2021

\section{REFERENCES}

[1] World Health Organization. WHO Coronavirus Disease (COVID-19) Dashboard [Internet]. WHO Health Emergency Dashboard. 2021 [cited 2021 Feb 21]. Available from: https://covid19.who.int/

[2] Yanti NPED, Nugraha IMADP, Wisnawa GA, Agustina NPD, Diantari NPA. Gambaran Pengetahuan Masyarakat tentang Covid-19 dan Perilaku Masyarakat di Masa Pandemi Covid-19. J Keperawatan Jiwa. 2020;8(3):485-90.

[3] Brahmana IB, Darmadi AANOY. Penindakan Terhadap Masyarakat yang Tidak Menggunakan Masker sebagai Pelaksanaan Protokol Kesehatan Baru di Provinsi Bali. J Kertha Desa. 2020;8(8):18.

[4] Quyumi E, Alimansur M. Upaya Pencegahan dengan Kepatuhan dalam Pencegahan Penularan Covid-19 pada Relawan Covid. JPH RECODE. 2020;4(1):81-7.

[5] Mujani S, Irvani D. Sikap dan Perilaku Warga terhadap Kebijakan Penanganan Wabah Covid-19. J Ilmu Polit Polit. 2020;11(2):219-38.

[6] Sarwono SW. Psikologi Lingkungan dan Pembangunan. Jakarta: Mitra Wacana Media; 2016.

[7] Jalaluddin R. Psikologi Komunikasi. Bandung: Rosada Karya; 1999.

[8] Lumban Gaol NT. Teori Stres: Stimulus, Respons, dan Transaksional. Bul Psikol. 2016;24(1):1-11.

[9] Siahaan M. Dampak Pandemi Covid-19 Terhadap Dunia Pendidikan. J Kaji Ilm.
[10] Saragih O, Sebayang FAA, Sinaga AB, Ridlo MR. Persepsi Mahasiswa terhadap Pembelajaran Daring pada Masa Pandemi Covid-19. J Penelit dan Pembelajaran. 2020;7(3):1-14.

[11] Dewi KH. Perempuan dan Pentingnya Responsif Gender dalam Penanganan Pandemi

[12] COVID-19 [Internet]. Pusat Penelitian Politik - Lembaga Ilmu Pengetahuan Indonesia (P2PLIPI). 2020

[13] Wiranti, Sriatmi A, Kusumastuti W. Determinan Kepatuhan Masyarakat Kota Depok terhadap Kebijakan Pembatasan Sosial Berskala Besar dalam Pencegahan COVID-19. J Kebijak Kesehat Indones [Internet]. 2020;09(03):117-24. Available from: https://journal.ugm.ac.id/jkki/article/view/584 84

[14] Amalia F, Brata AH, Sulistyo RT, Diofanu A. Analisis Tingkat Penerimaan Sistem ELearning Menggunakan Blog Gratis Sebagai Alternatif Media Pembelajaran pada Guru. J Teknol Inf dan Ilmu Komput. 2018;5(3):335.

[15] Hati K. Faktor-Faktor yang Mempengaruhi Penggunaan Internet sebagai Sarana Pendukung Proses Belajar Mengajar Berdasarkan Pendekatan "TAM". J Komput dan Inform Paradig [Internet]. 2007;9(1). Available from: https://ejournal.bsi.ac.id/ejurnal/index.php/par adigma/article/view/1146

[16] Ubaidillah A. Faktor-faktor yang Dapat Berpengaruh pada Kecepatan Internet [Internet]. detikInet. 2020 